This is an electronic version of an article published in International Journal of Disability, Development and Education Vol. 54, No. 1, March 2007, pp. 5-23. International Journal of Disability Development and Education is available online at:

http://www.informaworld.com/openurl?genre=article\&issn=1034-

$\underline{912 X \& \text { volume }=54 \& \text { issue }=1 \& \text { spage }=5}$

\title{
An Analysis of Accountability Policies in Finland and the United States
}

Tiina Itkonen $^{\text {a* }}$ and Markku Jahnukainen ${ }^{\mathrm{b}}$

${ }^{a}$ California State University Channel Islands, USA; ${ }^{b}$ University of Helsinki, Finland ${ }^{*}$ Corresponding author. California State University Channel Islands, One University Drive, Camarillo, CA 93012, USA. Email: tiina.itkonen@csuci.edu

This study examines student achievement and prevalence of students with disabilities in Finland and the United States (U.S.), by analysing international test scores, national reports, and special education legislation. The variables of interest include institutional design of each country, resources invested in and values surrounding public education, disability policies, and student diversity. Our findings indicate that the quality of the teaching profession, access to materials, intensive early interventions, equitable resource distribution, and values grounded on equity versus access are related to both student achievement and the prevalence of students with disabilities. We discuss implications of institutional arrangements and early intervention for policy formulation.

Keywords: Accountability; Disability policy; Early intervention; Equal access; Equity; Special education; Special needs

\section{Introduction}

The Program for International Student Assessment (PISA, 2003) results ranked 15-year-old Finns among the top performers in mathematics and reading among the 41 countries included in PISA. Finland also had the narrowest gap between the highest and lowest performing students and had low between-school variance. Following the publication of the PISA results, scholars and policymakers across the world traveled to Finland to examine the policy and instructional contexts within which public education occurs (Grubb, 2005). U.S. students scored below average on the same tests even though the United States ranked fourth in K-12 annual expenditures for public education, behind Denmark, Switzerland, and Austria (Organization for Economic Cooperation and Development [OECD], 2001).

While test results (outcomes) and expenditures (inputs) tell part of the story of public education, we aim here to analyse institutional structures and designs that might help explain variation in educational achievement of students in the U.S. 
and Finland. We believe that our study is timely given that, in the U.S., reforms that aim to improve educational achievement of all students, and, simultaneously, to narrow achievement gaps of particular subgroups (e.g., disadvantaged students and students with disabilities), have been guided primarily by federal mandates, which emanate from the No Child Left Behind (NCLB) Act (2002). These reforms are based on the premise that student achievement will improve when individual schools are held accountable through the mechanisms of establishing standards and evaluating performance of students, and subgroups of students, on annual standardised tests. "Failing schools" (i.e., schools that fail to demonstrate adequate yearly progress, as evidenced by students' scores on these standardised tests) are subject to sanctions. These sanctions range from relatively minor actions, such as providing tutoring, to major actions, such as reforming the school staff and administration or having students transfer to other schools. We believe that efforts to improve educational outcomes for all students, including those with disabilities, in Finland have followed a path that differs, in important ways, from that of the United States. In short, our study should interest scholars and policy-makers studying school improvement, response to intervention (Fuchs \& Fuchs, 2005; Fuchs, Mock, Morgan, \& Young, 2003; Vaughn \& Fuchs, 2003), and early intervention.

\section{Conceptual Framework}

\section{Institutional Design}

We conceptualise public education as situated in the broad societal context (e.g., Hochschild \& Scovronick, 2003), and ground it in institutional theory with the premise that education is the incremental sum of policies across multiple institutions, with each institution influenced by its own unique norms and values that drive policy problems, solutions, and outcomes (Kindgon, 1995; March \& Olsen, 1989). This implies that what takes place in individual classrooms is a synthesis of relevant educational laws, local policies, and court interpretations. Indeed, variability in interpretation increases as a policy filters down from the legislature to a classroom teacher. This variability is partially due to the complex nature of school systems and the fact that local implementers must perform their job in an environment of ambiguity, uncertainty, and multiple, competing goals (Weatherly \& Lipsky, 1977; Wilson, 1989).

Institutional design influences how educational entities are organised and whether the locus of decision-making rests primarily at the local, intermediate (municipality, state), or national level. We propose that the locus of decisionmaking further affects how teaching is organised and delivered; for example, whether schools teach the same academic content to their students, and whether their teachers hold comparable degrees. 


\section{Resources Invested in Public Education}

Recent research suggests that resources, broadly defined, and the equitable distribution of those resources across schools, affect achievement (Chiu \& Khoo, 2005). Students score higher in reading, mathematics, and science when they have more resources in their country (e.g., high gross domestic product), school (e.g., certified teachers), and family (e.g., higher parental education level) (Chiu \& Khoo).

Student achievement is, thus, correlated with resources and how resources are distributed. Under-achieving students in the U.S. tend to be located in states that spend less on education, in districts and schools that have fewer resources, or in classrooms that offer fewer resources than other classrooms in the school (e.g., credentialed teachers, challenging curriculum) (Rothstein, 2000). Similarly, Powers (2004) examined school and school district characteristics (i.e., teacher characteristics, facilities, textbook spending) against California's measure of school performance. Powers found that resources and school performance are positively correlated. Resource-rich schools and school districts score higher on the performance index, while resource-poor schools and school districts score lower on the performance index.

Socio-economic status (SES) is indirectly related to resources. That is, underperforming schools tend to be clustered in poor school districts and serve students who come from low-income and minority backgrounds. According to the Harvard Civil Rights Project (2005), a systematic performance gap exists between U.S. students who are poor or from minority backgrounds and their more affluent peers. At 6-years-old, low-income students score considerably lower than affluent students on vocabulary knowledge (Mayer, 1997). This difference is equivalent to about 9 months of cognitive growth for an average child. Rothstein (2000) reports that students who live in poverty have a dropout rate of $25 \%$ (and up to $50 \%$ in urban school systems), while students from highincome families have a dropout rate of $2 \%$.

\section{Values Surrounding Public Education}

Legislatures, state education agencies or municipalities, and local school districts have a variety of institutional histories, values, beliefs, norms, and rules (March \& Olsen, 1989). In the U.S., the role of state is to provide equal opportunity for the collective good of the nation, after which it is the responsibility of the citizens to achieve and succeed (Hochschild \& Scovronick, 2003). The idea is that everyone can "make it", if they so choose and work hard (Hochschild \& Scovronick). Thus, the responsibility in the U.S. rests largely on the individual. In Finland and in many other European countries, the role of the state is not only to provide an opportunity, but to support its citizens in their quest for a decent standard of living (e.g., work, housing, health, higher education) (Hokenmaier, 1998). Achievement is conceptualized as a collective responsibility. 
Accountability policies stemming from an equal opportunity (U.S.) versus an equity (Finland) framework operate from a different set of assumptions and affect how policy problems are defined and solved. Individual achievement is a construct and can be defined from many perspectives. Absolute achievement refers to reaching a higher level of thinking or well-being compared with where one started (Hochschild \& Scovronick, 2003). Thus, evaluation highlights the progress of the individual across time. One policy implication, here, would be to provide more educational resources to some students versus others so that everyone can achieve the absolute level, regardless of individual or family variables. Relative success, on the other hand, compares individual or group achievement to that of another individual or group (Hochschild \& Scovronick). For example, first-generation college students have attained more educationally than their parents' or grandparents' generations. Finally, competitive success implies not only comparisons to other groups, but sorting those who succeed from those who do not. To define success from this perspective implies ranking schools and students and distinguishing those who succeed and those who fail based on some criteria. A policy based on the assumption that the capacity exists for performance, but that performance is not at an adequate level for whatever reason (e.g., shirking), is likely to result in the use of sanctions as an enforcement mechanism (McDonnell \& Elmore, 1987). Withdrawing funds from "failing" schools contingent upon unsatisfactory performance is one outcome that is consistent with a policy based on competitive success. Conversely, a policy based on absolute success of students would provide "under-performing" schools capacitybuilding tools, such as materials, facility improvements, teacher training, and curricular support.

Another value underlying public education is early intervention and whether it is or should be universally provided. PISA (2003) results indicate that 15-yearolds who attended preschool for at least one year had a statistically significant performance advantage over students who did not attend preschools. In fact, in all countries $(N=41)$, students who attended preschool for more than one year had an eight score point advantage in mathematics performance, when controlling for SES.

\section{Disability Policies}

In 1975, the U.S. led the world in passing federal legislation, the Education of All Handicapped Children Act, which guaranteed free, appropriate, public education for every child, regardless of the type and degree of disability. One unintended consequence, however, was the creation of two separate systems-general education and special education. Many students with disabilities did not have access to the core curriculum experienced by their non-disabled peers in general education (McDonnell \& McLaughlin, 1997).

In Finland, special education legislation is relatively newer than in the United States. The Comprehensive School Act of 1970 guaranteed equal educational opportunity for all children. In 1985, the responsibility for educating students with 
moderate intellectual disabilities was transferred from social welfare agencies to public schools. Through 1997, however, social welfare agencies remained responsible for educating students with the most severe intellectual disabilities. In 1998, the Comprehensive Education Law established an individualised education programme for the first time. The law also framed special education around supports (i.e., funding tied to the individualized education programme, not placement) and stated that it is the pupil's right to receive education in the general education class (Jahnukainen, 2003).

\section{Diversity}

Finally, it is necessary to discuss the demographic diversity of the two countries. Finland remains relatively homogeneous, despite a recent influx of immigrants, for example, from Somalia. Of Finnish PISA test-takers, 98\% were born in Finland, seven percentage points above the OECD average of $91.4 \%$ for native born testtakers. U.S. geography varies from rural states and school districts to highly urban, inner-city contexts, each representing their own challenges. The

student population in the U.S. is much more diverse linguistically, ethnically, culturally, and socioeconomically than in Finland. PISA results indicate that when first-generation students represent more than 3\% of PISA participants, as in the U.S., native-born and first-generation students have large and statistically significant differences in achievement, with native students scoring higher. Nonnative students tend to lag behind their native peers.

\section{Research Question}

The guiding question of our study was as follows: What institutional factors help to explain student achievement in the U.S. and Finland? Variables of interest included the institutional design of each country, resources invested in public education, values regarding public education, disability policies, and student diversity.

\section{Method}

We used a comparative case study design and sequential mixed methods (Morse, 2003) to address our research question. We collected and analysed quantitative information from the PISA database, as well as educational statistics on the United States and Finland. Then we systematically coded and analysed narrative data from document sources. Quantitative data and statistics suggested patterns and qualitative analysis helped us probe deeper into the context of these patterns (Creswell, 2003). We conducted comparisons across coded data from education legislation, regulations, and policies enacted, respectively, by the Finnish Ministry of Education and the U.S. Department of Education. We further examined institutional arrangements of national and local government entities 
involved in policy design and implementation, including policies from other ministries and departments, by coding them in so far as they related to public education.

We collected data on students eligible for special education and special education placements from national statistical services and reports, including the National Center for Education Statistics (U.S.), U.S. Department of Education (2000, 2005) Office of Special Education Program's Annual Report to Congress, OECD's (2001) Education at a Glance, and Tilastokeskus [Statistics Finland]. We used the PISA database to collect data on international mathematics and reading achievement, as well as achievement predictors.

We developed several indicators that were designed to act as proxies for our variables of interest. We used the locus of policy decisions (e.g., centralised versus de-centralised) as an indicator of institutional design. Indicators for resources included sources of funding, socio-economic status, teacher training, and teacher retention. We conceptualised values regarding public education around equal opportunity versus equity, and analysed the purpose of accountability and early intervention policies, as stated in legislative and policy documents. We examined disability policies by analysing the countries' percentages of students with disabilities from the total student population, and the educational placements of students with disabilities. Finally, we defined student diversity as the percentage of immigrant students and non-native speakers taking the international high stakes examination, as well as the percentage of ethnic students in special education.

\section{Results}

\section{Institutional Design}

Institutional design differs in Finland and the U.S. The U.S. government is based on federalism, and the Constitution limits the federal role in many domestic policy domains. The educational system is decentralised as a result of the vertical independence of various branches, as responsibilities are divided among federal, state, and local education offices. Public education in the U.S. has historically been the function of local communities and school boards.

The role of U.S. federal legislation has been to ensure equal access and opportunity through grant-in-aid programs (e.g., the Individuals with Disabilities Education Act [IDEA]) and civil right laws (e.g., Section 504 of the Rehabilitation Act). Only in the past two decades has public education evolved from local to state control with the standards-based and accountability movements. More recently, the federal government has become increasingly involved in instructional policy with Goals 2000 and the enactment of NCLB (McDonnell, 2005; Superfine, 2005). Although the federal government can issue mandates to states that receive federal funding (such as the accountability policies articulated under NCLB), the de-centralisation of the educational system still results in 
variation, for example, in the educational standards across states and curricula across districts within a state. Variation in student achievement in the U.S. might, thus, be a by-product of de-centralised decision-making; different jurisdictions have different educational goals, organisations, and delivery systems.

In contrast, comprehensive education was a national initiative in Finland, enacted in the 1920s (Jahnukainen, 2001, 2003; Kivirauma, 2001). Finland has a national curriculum, overseen by the Ministry of Education. Although municipalities and schools have had broad latitude since the 1990s, schooling is based on national goals that guide local decisions. The individualised education programme content is also based on the national curriculum, with individual adaptations or modified goals as needed. National goals imply less variation in educational goals and curricular content, and, thus, might account in part for the low between-school variance in student performance in Finland.

In summary, the locus of decision-making in Finland and the U.S.-whether, and how much, local versus federal agencies have authority over schooling-is an institutional design matter that might affect what and how subject matter is taught across the country. Our results do not permit conclusions about the role of a national curriculum in overall student achievement. However, in the case of Finland and the U.S., the data suggest that national goals with some local discretion are associated with relatively lower variability in student achievement, whereas more localised discretion is associated with relatively higher variability in student achievement.

\section{Resources Invested in Public Education}

Socio-economic status. Between-school variance in student achievement in Finland (approximately $3 \%$ of average variance in student performance) is among the lowest of countries listed in PISA, at approximately one-tenth of the OECD average (33.6\%). Moreover, in Finland, SES accounts for less than $5 \%$ of performance variance across schools. In other words, student achievement varies for reasons that are not related to students' SES. The U.S., in contrast, has comparatively large socioeconomic disparities. In the U.S., the betweenschool variance that is attributable to student SES is approximately $20 \%$ of the average variance, although still below the OECD average.

In the PISA mathematics subtest, the mean score of U.S. students $(M=483)$ is statistically significantly below the OECD average $(M=500)$. Students' SES impacts this score more, on average, than in other countries. In contrast, for the same mathematics subtest, the mean score of Finnish students $(M=544)$ is statistically significantly above the OECD average, and students' SES accounts for less than $5 \%$ of performance variance across schools. In the U.S., the greater the SES advantage of one student over another, the greater the impact on their mathematics scores. In Finland, differences in the mathematics subtest are not attributable to SES. 
Funding. With the exception of Hawai'i, which operates under one board of education, all states in the U.S. have multiple local school districts governed by their respective school boards. These local districts fund almost one-half of the total expense of public education. The U.S. federal government funds about $8 \%$, and states fund the remaining cost. Most local funds are raised via taxes based on the property wealth of homes and businesses located within the geographic boundaries of the local school district. School districts located in areas with expensive homes and large businesses receive more revenues from property taxes than school districts located in areas with little property wealth. Thus, socio-economic disparities are inherent in the property-based, local funding of U.S. public education and, consequently, in student achievement (Chiu \& Khoo, 2005).

In Finland, the Ministry of Education funds education based on the number of students per school. Students with disabilities are funded with a weighted formula of 1.5 times the expense of a non-disabled student. Students who receive part-time special education in the form of intensive interventions are not funded as "special education students". They are funded at the standard 1.0 weight. In addition, some municipalities award extra funds for schools with an overrepresentation of disadvantaged students.

Teacher training. In Finland, all teachers, including Kindergarten teachers, hold a Master's degree that is based on national standards, and teaching is a high-status profession (Simola, 2005). Eight state universities (out of 21) grant multiple-subject and single-subject credentials. Five universities award special education degrees. All universities have a nationally designed teacher education curriculum, although individual course syllabi and course design vary across the universities. Finland has no private universities.

Credentialing requirements vary in the United States. This variation stems from the original institutional design of local and, later, state control in education matters. A teacher who received a credential in one state but who moved to another state usually must complete a subject matter examination or additional course work to obtain a credential, unless the states have reciprocal agreements. As education policies have evolved from local control to the states and, more recently, to the national level, teacher credentialing has changed. The National Board for Professional Teaching Standards is an attempt to provide a nationwide certification. It measures a teacher's practice against high and rigorous standards through portfolios, student work samples, and videotaped analyses of teaching and learning. However, a national credential is a professional choice at this point, and across-state variation still exists. Moreover, recent proliferation of alternative routes and programmes for teacher credentialing have fostered higher levels of within-state and across state variation in the United States.

Teacher retention. The U.S. has experienced teacher shortages of qualified special education teachers since the enactment of the Education of All Handicapped Children Act of 1975 (U.S. Department of Education, 2003). In $2001-02,12 \%$ of the special education teaching force was not certified for their 
positions ("23rd Annual Report to Congress"). The Bureau of Labor Statistics (2006) further projected a demand for more than 92,088 additional pre-

Kindergarten to Grade 12 special educators by the year 2014. Teacher retention continues to present problems across the country as an estimated $25 \%$ of beginning teachers do not teach for more than two years, and $40-50 \%$ leave their professions within the first five years of their career (Kirby \& Grissmer, 1993). Poor working conditions have been cited as a factor that contributes to chronic shortages and high attrition of special education teachers (Brownell, Sindelar, Bishop, Langley, \& Seonjin, 2005). Indeed, in some states, more than enough certified special education teachers are available to fill the special education positions held by uncertified teachers (Schrag \& McDougall, 1997). However, many of these certified teachers have opted out of their special education positions and become teachers in general education, or they have departed education altogether, citing poor working conditions as an important reason why they chose to depart (Brownell et al., 2005)

Curiously, there is no Finnish word for "teacher retention". The teaching profession is stable, with only $7.2 \%$ of teachers leaving their positions (Statistics Finland, 2002). According to PISA 2003, Finland was among five countries whose principals reported that teacher shortage was least likely to hinder instructional capacity. According to the principals surveyed in the PISA report, less than $10 \%$ of Finnish students were affected by a teacher shortage in comparison with $22 \%$ of U.S. students.

\section{Values Regarding Public Education}

Purpose of high-stakes assessments. An analysis of legislation and regulations reveal a fundamental difference in the purpose of high-stakes examinations in the two countries. In the U.S., the NCLB indicates that standardised examinations will enable stakeholders to understand and compare performance of schools against the standards for proficiency as set by states. The media often report test results to rank schools in so far as they meet standards and make adequate yearly progress toward those standards. In Finland, the goals for assessment as spelled out in the public education law include: (a) to inform national policy, (b) to inform local decision-making, and (c) to support teaching, learning, and school development (Perustusopetuslaki, 1998, Chapter 1, §2). The last objective is one of the major differences between the two countries. In Finland, the high-stakes examination results are not published in newspapers or in other media for the public. Examination results do not serve the purpose of ranking schools. Rather, test results enable each school to improve their processes of teaching and learning. The results of standardised tests do not affect the funding of schools.

The concept of competitive, normative success (i.e., success defined in relation to the failure of others) has lead to standardised testing in the United States. Such testing sorts students and schools by those who do succeed versus those who do not succeed. Testing policies in Finland are framed by the concept 
of absolute, individual success. Standardised tests are not administered for purposes of normative comparisons because success is defined according to an individual student's achievement over time, or relative to standards. Test results do not require rankings. Rather, test scores are used to determine what individualised supports pupils and schools need to reach educational goals.

Early intervention. Our analysis supports PISA findings that preschool attendance affects later educational achievement. In the U.S., preschool is not universal, and students who attended preschool for one year or less, had a 40 score point deficit compared with those children who attended preschool longer (PISA, 2003).

Finland, on the other hand, has a policy that states that early childhood education is every family's right, subsidised by the municipality (Perustusopetuslaki, 1998, Chapter 2, §4). According to PISA (2003), 87\% of Finnish children attended preschool for more than 1 year. In addition to universal preschool, school readiness is a core value in Finland's early intervention programs. Pre-natal and post-natal care is paid by taxes and is free for families, until the child enters Kindergarten. Each child has a health examination, at the age of five, to predict potential learning difficulties at school, and, if needed to provide preventative supports. Children who receive these supports are not formally placed in special education or given a diagnosis, unless the child experiences more significant challenges.

Through IDEA, the U.S. has also instituted early intervention services for infant and toddlers, and preschool aged children who have disabilities or developmental delays. These services are free under IDEA. In 2000, 232,815 infants and toddlers received early intervention services. This figure represents about $2 \%$ of all U.S. infants and toddlers, according to July 2000 population estimates from the U.S. Census Bureau (2000). In 2001, 620,195 preschoolers with disabilities, or about $5 \%$ of all U.S. preschoolers, received special education services. One major difference between services in the U.S. and those provided in Finland is that, in order to get served in the U.S., a child has to be found eligible under IDEA. Children who do not qualify do not receive these services for free with the use of public funds. Likewise, Headstart is another publicly funded, early intervention programme in the U.S. Headstart targets SES-disadvantaged children. As with special education and preschool services in the U.S., a child has to meet specific eligibility requirements to qualify for Headstart services.

Findings support our contention about differences in the role of government in the two countries. The role of government in the U.S. is to provide equal opportunity for the collective good. When an individual lacks opportunity (e.g., because of a disability), federal laws, such as IDEA's Part C early intervention provision, provide access to services to ameliorate barriers that the individual might experience. The core value of equity, however, in Finland means that early childhood services are extended to the entire population. This equity value is part of primary level prevention of social exclusion in Finland (Jahnukainen \& Jarvinen, 2005). 


\section{Disability Policies}

Prevalence of students. Approximately $12 \%$ of U.S. school-aged children (ages 6-21 under IDEA) receive special education services (U.S. Department of Education, 2005). In Finland, approximately $28 \%$ of all school-aged children (ages 6-17) receive special education and intensive interventions (Statistics Finland, 2005). Finland had $7.2 \%$ and the U.S. 3.6\% of PISA participants identified as having special education needs (Country Representatives Meeting, 2005).

Distribution of students by lower and upper grade levels. Analysing disability prevalence by students' grade levels helps to illuminate some of the aforementioned differences between the U.S. and Finland. For the 2001-02 school year, the population of students with disabilities who received services in the U.S. was distributed across lower and upper grades in the following manner. Students in Grades 1 to 6 constituted $48 \%$ of the aforementioned population. Likewise, students in Grades 7 to 10 constituted $48 \%$ of the aforementioned population (U.S. Department of Education, 2005). In Finland, however, out of the total population of students with disabilities in Grades 1 to 9, students in Grades 1 to 6 constituted approximately $70 \%$ and students in Grades 7 to 9 constituted about $28 \%$ of the population. Compared with those in the U.S., students in Finland tend to receive services more so during earlier grades and less so during later grades. Indeed, students with disabilities in Finland tend to "exit" or not to need services as they grow older, whereas their counterparts in the U.S. continue to receive services throughout their school career.

A similar pattern appears for students with learning disabilities. In the U.S., students with learning disabilities account for $18 \%$ of the special education population for 6 to 11-year-olds and 30\% of the special education population for 12 to 17- year-olds (U.S. Department of Education, 2005). It appears that some students are identified as having learning disabilities at a later age. A contrasting pattern exists in Finland. Students with reading, writing, or mathematics problems comprise approximately $40 \%$ of the special education population of Finnish students in Grades 1 to 6 and 13\% of the special education population of Finnish students in Grades 7 to 9 .

Unlike the aforementioned patterns for students with disabilities, in general, as well as students with learning disabilities, the distribution by grade level of students with speech and language disabilities is about the same in the two countries. Indeed, the numbers of students eligible for and receiving such services decrease drastically from earlier to later grade levels in both Finland and the United States.

The Finnish school system provides interventions in the primary grades (Grades 1 to 6) and then exits the majority of students with disabilities. Early intervention is not articulated explicitly in legislation or policies, but, rather, has been implemented as best practice (Simola, 2005). We must note, however, that the prevalence of students with emotional and behavioural disabilities, and "other" disabilities, is constant across age groups in Finland. In addition, the 
percentage of students with problems in foreign languages increases in Grades 7 to 9, precisely at the time when at least two new languages are introduced.

Figure 1 depicts the prevalence of students by source of learning difficulties across age groups.

These findings are of interest in the light of the reauthorised IDEA (2004), and have policy implications as states and schools districts have the option to implement response-to-intervention to identify students with learning disabilities. Although it is beyond the scope of this paper to further examine the intervention model of Finland, we believe that data indicate that intensive part-time interventions, in the context of the Finnish national curriculum, allow students with academic difficulties to master skills, to "exit" special education, or to not become identified as having disabilities.

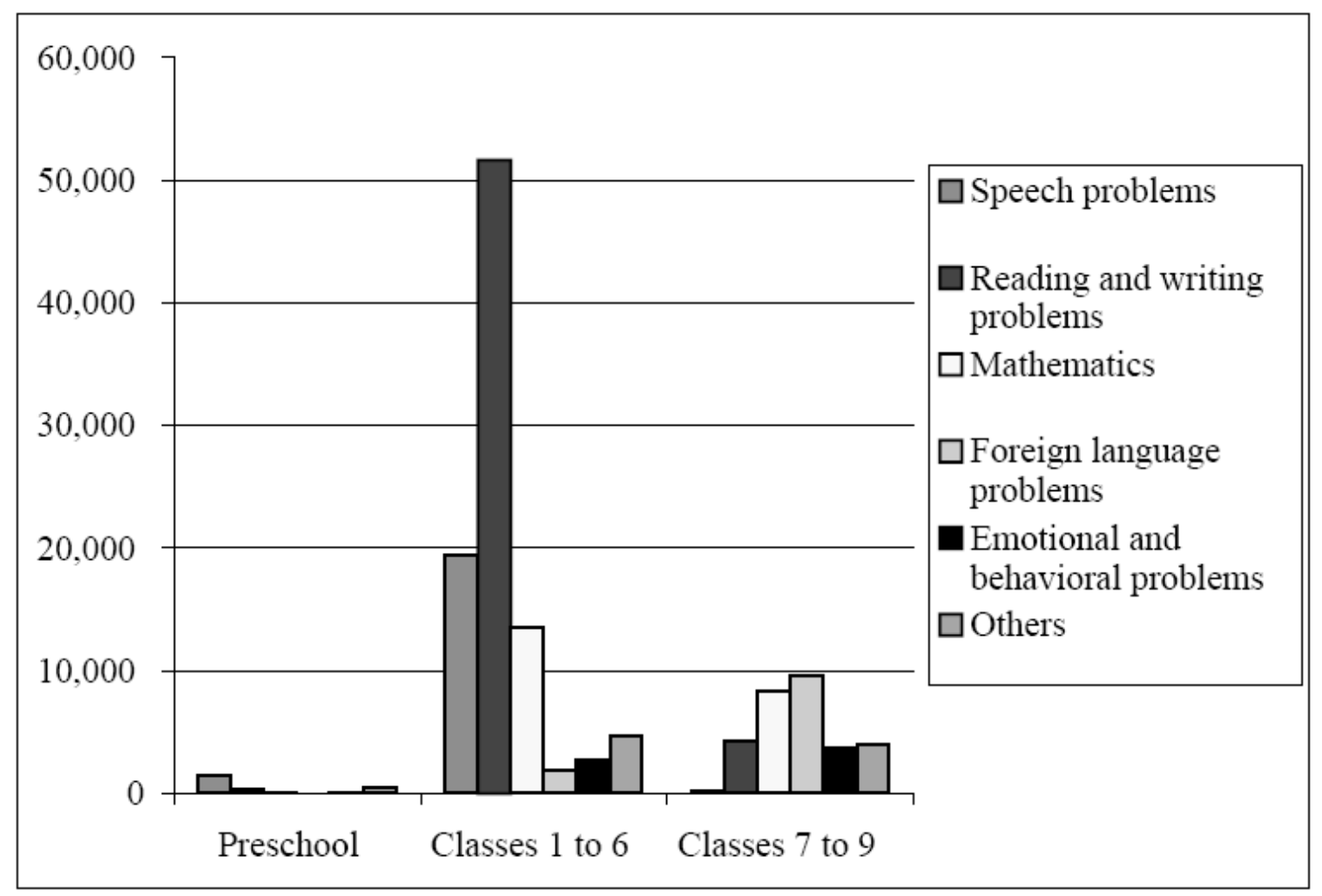

Figure 1. Number of Finnish students with disabilities receiving part-time special education interventions, by age group

Educational placements. As seen in Table 1, the majority of U.S. students with disabilities are educated in regular school buildings (96\%). Of these students, $47 \%$ spend part of their day outside the general education class, but for less than $21 \%$ of their school day (e.g., 1.2-h out of a 6-h school day). Approximately $4 \%$ of students with disabilities are educated in separate environments, both public and private.

A similar situation exists in Finland. Most students with disabilities receive services in a public school building (94\%). However, students who have learning difficulties in reading, writing, or mathematics, and receive part-time 
interventions, are not considered "disabled" even though they receive special education interventions.

The intervention model precedes any formal placement or identification of students. The data presented in Table 1, however, indicate that students with learning difficulties in Finland tend to spend more of their day in their general education classrooms compared with their U.S. peers.

Table 1. Percentage of students with disabilities and their special education service location Service location U.S. students Finnish students

\begin{tabular}{lcc}
\hline Service location & U.S. students & Finnish students \\
\hline Regular school building & 96 & 94 \\
Outside general education class for $<21 \%$ of school day & 47 & 81 \\
Outside general education class for $21-60 \%$ of school day & 30 & 5 \\
Outside general education class for $>60 \%$ of school day & 20 & 8 \\
Separate environments & $4^{\text {a }}$ & $6^{\text {b }}$ \\
\hline
\end{tabular}

Note: ${ }_{\mathrm{a}}$ Includes public and private residential facilities, other separate facilities, and homebound and hospital environments. ${ }_{b}$ Includes residential and hospital schools.

\section{Diversity}

Immigrant (first-generation and non-native born) students systematically score lower than native students across OECD countries. In the U.S., the discrepancy between immigrant and native students is about 50 points in reading and about 37 points in mathematics. These discrepancies are similar to the mean discrepancy for OECD countries overall (i.e., 47 points in reading and 39 points in mathematics). In Finland, however, the discrepancy between immigrant and native students is particularly high (i.e., over 60 points in reading and about 40 points in mathematics). Possible reasons might include that educational disadvantages already present in the country of origin can get magnified in Finland, even when measures of educational achievement might have increased. The effect size of PISA performance for students who speak a foreign language at home most of the time is negative and large in Finland (-46.00), whereas in the U.S. it is small yet positive (3.55) (PISA, 2003). It is possible that the task of meeting immigrant children's educational needs is relatively newer to the Finnish school system, in comparison with the United States.

Language acquisition is another factor that is likely to impact on educational achievement. Finland is a relatively homogeneous country in terms of language, especially when compared with the United States. In Finland, only about 3\% of students between ages 7 and 15 speak a foreign language at home. Immigrant students receive transitional instruction and services for the first 6 months, after which, if needed, they receive Finnish as a foreign language instruction, and instruction in their native tongue. Figures 2 and 3 depict the discrepancies 
between native and immigrant students, in mathematics and reading scores, for students in the United States, Finland, and OECD countries overall.

Another aspect of diversity is the prevalence of children from ethnic backgrounds in special education. In 2002, about $7 \%$ of immigrant children received special education services in Finland. This percentage suggests that immigrant children are underrepresented in receiving special education services in Finland. In the United States, students of certain minority and ethnic groups continue to be overrepresented in special education. According to the "25th Annual Report to Congress" (U.S. Department of Education, 2005), Black students continue to be overrepresented across all disability categories. American Indian/Alaskan Native students are also overrepresented, to a lesser degree. In addition, some ethnicities in the United States are underrepresented in special education. We will not discuss reasons for overrepresentation and underrepresentation, but recommend that readers consult pertinent research (cf., Harry \& Klingner, 2005).

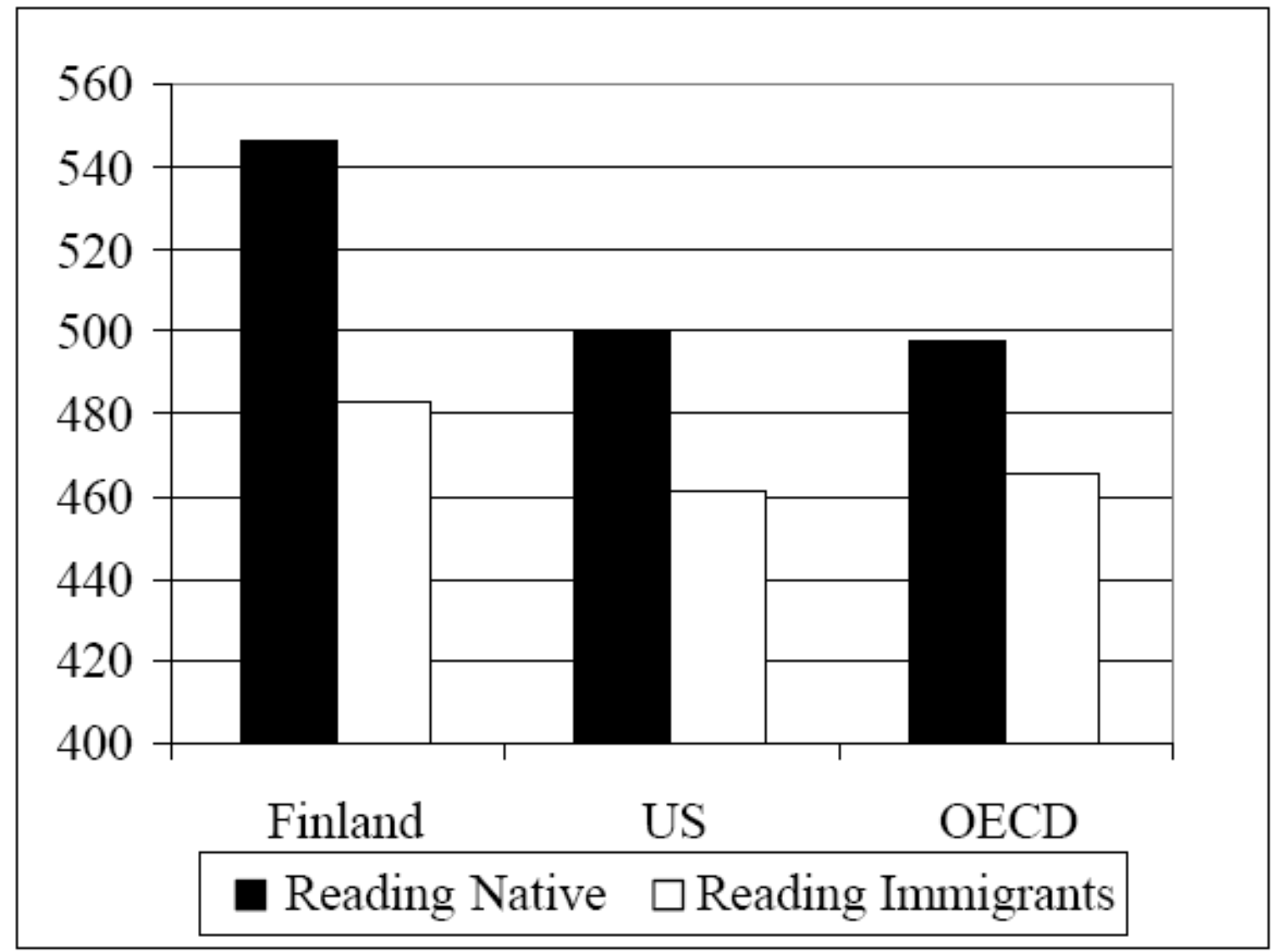

Figure 2. Reading means in PISA 2003 for native-born and immigrant students 


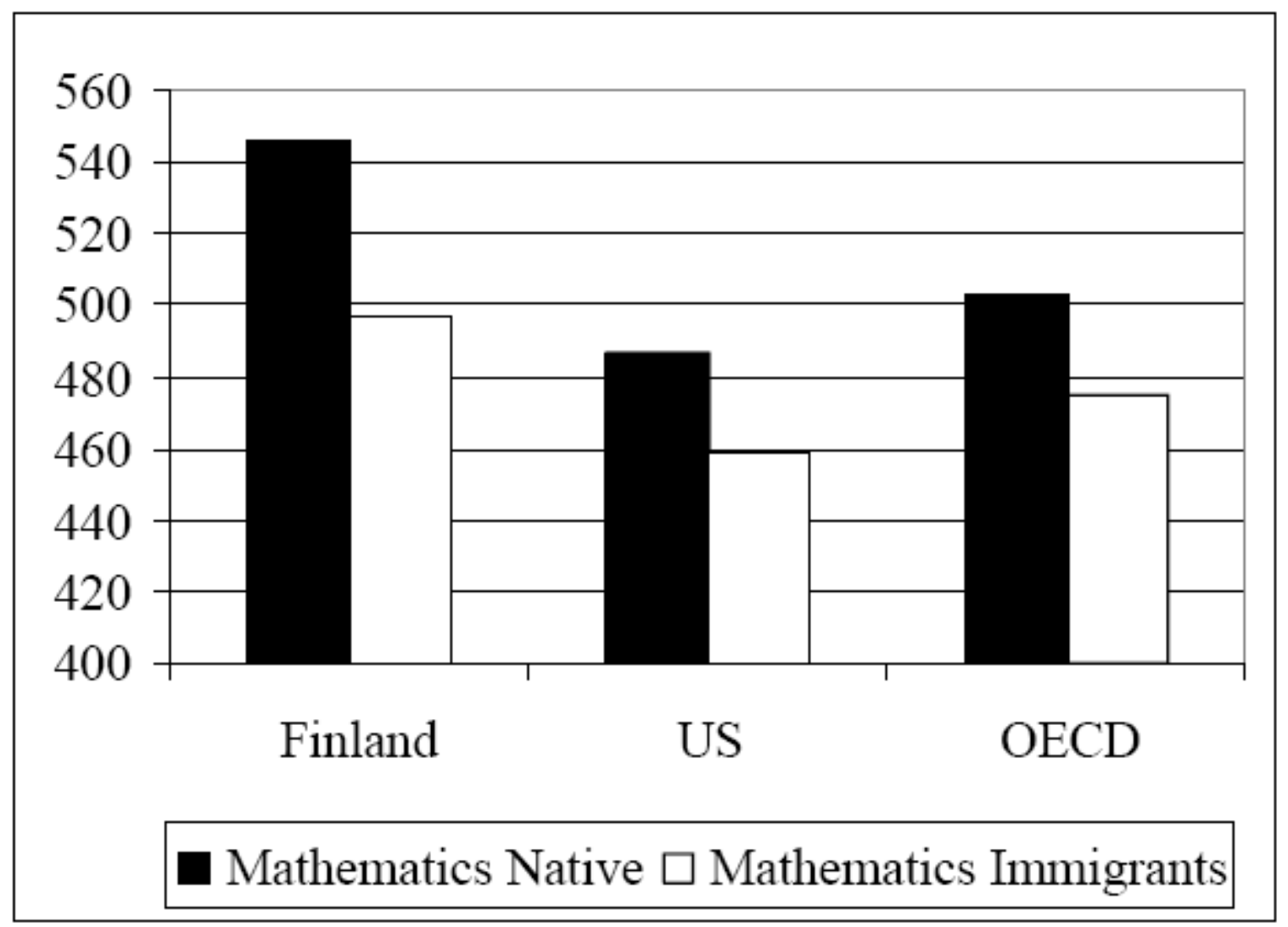

Figure 3. Mathematics means in PISA 2003 for native-born and immigrant students

\section{Discussion}

Our findings contribute to the growing body of knowledge that conceptualizes accountability policies beyond test scores (e.g., Chiu \& Khoo, 2005; Hochschild \& Scovronick, 2003). Findings presented here suggest that students' academic achievement is related to: (a) national goals with local discretion, (b) resources and their distribution, and (c) institutional values surrounding public education (e.g., early intervention). We believe that accountability and achievement are constructs that are much broader than individual or aggregated test scores.

Accountability and achievement can be defined from multiple perspectives. Student performance on high-stakes tests can be framed as: (a) accountability of schools (e.g., did schools do their job in teaching the core curriculum?), (b) equal access (e.g., did all students, including those with disabilities, have access to education?), or (c) equity (e.g., were essential education resources distributed equitably across students?). Framing affects policy construction (Itkonen, 2005). An accountability policy that is framed as success relative to others tends to sort schools as those who succeed versus those who fail. A policy based on comparative success is more likely to use sanctions, such as withdrawing funds from failing schools, as an implementation tool. In contrast, when the policy is framed around equity, and success is defined in absolute terms for each student, 
it is likely to be implemented with capacity building instruments, such as training and additional resources (McDonnell \& Elmore, 1987).

Other scholars have suggested that resource distribution is directly linked to achievement (e.g., Chiu \& Khoo, 2005; Rothstein, 2000). Resource allocation is a way to decrease between-school variance on achievement. In the U.S., highachieving students benefit disproportionately from a higher level of "endowments" (PISA, 2003). These students live in school districts with high local funding bases, have higher SES, have access to credentialed teachers, and benefit from quality facilities and materials. This resource-rich endowment creates strong opportunities for high academic achievement. Unfortunately, the inherently lower level of resource endowment in poorer school districts acts as a constraint, limits the potential for achievement, and manifests as lower student achievement. If the goal is to increase the performance of all students-including those with disabilities and those from low SES backgrounds-a coherent resource allocation strategy would seem to require a two-fold approach. First, all schools and students might benefit from additional resources. Second, economic efficiency suggests that scarce resources are best allocated to their most highly valued use, where the additional resources will produce the greatest returns.

In essence, the high-scoring countries on PISA have used the aforementioned strategy to allocate resources. For example, countries like Finland and South Korea provide extra funding and capacity resources for schools with disproportionately more disadvantaged students. Finland further provides intensive early intervention to all children under the age of five, and intensive special education interventions to students who struggle academically, so that those students either do not need to be diagnosed as having disabilities or can be exited from special education interventions after Grade 6 . We believe that changing the endowments, in essence, "levels the playing field".

We propose that one size does not fit all; resource distribution needs to be tailored to the specific needs of the jurisdiction and student population (PISA, 2003). For example, low-performing students, regardless of SES, would benefit from policies that target performance through prevention or early intervention. Students from disadvantaged backgrounds and schools in deprived areas, on the other hand, might benefit from policies that emphasise improving the economic circumstances of students from disadvantaged families. Finally, universal policies indicate major school reforms, to change the organisation and practice of the entire educational system. Depending on the need of the individual school, district, and area, one or a combination of these policies could be implemented.

In Finland, a comparatively low percentage of students come from disadvantaged backgrounds, and school performance is unrelated to SES. Policies that specifically target disadvantaged students thus would not reach all low-performing students, which is why Finland has implemented performancetargeted and universal educational policies. Given much wider variation among U.S. versus Finnish schools, and the relation of SES to academic achievement, policy-makers might wish to tailor education policies according to the need of the school and the district. Low-performing schools might need a combination of performance-targeted interventions for low-performing students, as well as 
additional resources such as trained teachers, innovative curriculum, access to materials, and safe facilities (Powers, 2004).

\section{Study Limitations}

We examined institutional variables that characterise public schooling in Finland and the U.S., and possible relations to what students do and do not learn, as measured by standardised tests of academic achievement. Our study was descriptive and exploratory, and we purposefully selected two cases-Finland and the U.S. - to illuminate, particularly, differences in institutional variables that are probably related to schooling and student achievement. Our study design, method, and analysis do not permit cause-effect conclusions between the variables of interest and academic achievement. Moreover, we did not propose a model that quantified the direction and degree of relations between the variables of interest in our study. However, we believe our findings suggest worthy topics and potential causal links for researchers to investigate.

Two additional limitations of our study are that we did not use an external audit (Shoukri, 2003) to verify the link between data and findings, and we did not calculate agreement indices for coding. We did, however, use the method of consensus (i.e., between the first and second authors) when we coded data, identified emerging themes, and formulated findings.

One intended outcome of our inquiry was to broaden the discussion on accountability and achievement by examining institutional arrangements and subsequent education policy choices. We hope that our descriptive framework, grounded in social science, will expand findings from comparative and predictive studies that illuminate how to increase student achievement and, concurrently, narrow achievement gaps between specific groups of students. Finally, we hope that our analysis stimulates international interest in considering, implementing, and evaluating early intervention services as a means to promote positive outcomes for all students.

\section{References}

Brownell, M. T., Sindelar, P. T., Bishop, A. G., Langley, L. K., \& Seonjin, S. (2005). Special education teacher supply and teacher quality: The problems, the solutions. In T. M. Skirtic, K. R. Harris, \& J. G. Shriner (Eds.), Special education policy and practice (pp. 103-128). Denver, CO: Love Publishing.

Bureau of Labor Statistics. (2006). Employment projections statistics. Retrieved February 2, 2006, from http://www.bls.gov/emp/home.htm.

Chiu, M. M., \& Khoo, L. (2005). Effects of resources, inequality, and privilege bias on achievement: Country, school, and student level analyses. American Educational Research Journal, 42(4), 575-603. 
Country Representatives Meeting (2005, November 21-23). 14th Special Education Needs, Disabilities, Difficulties and Disadvantages. Washington, DC.

Creswell, J. W. (2003). Research design: Qualitative, quantitative, and mixed methods approaches ( $2^{\text {nd }}$ ed.). Thousand Oaks, CA: Sage Publications.

Fuchs, D., \& Fuchs, L. (2005). Responsiveness-to-Intervention: A blueprint for practitioners, policymakers, and parents. Teaching Exceptional Children, 38, 5761.

Fuchs, D., Mock, D., Morgan, P. L., \& Young, C. L. (2003). Responsiveness-tointervention: Definitions, evidence, and implications for the learning disabilities construct. Learning Disabilities Research \& Practice, 18(3), 157-171.

Grubb, N. (2005, June 5). Everything I really need to know I learned in Helsinki. Los Angeles Times, p. M1.

Harry, B., \& Klingner, J. (2005). Why are so many minority students in special education? New York: Teachers College Press.

Harvard Civil Rights Project. (2005). Retrieved June 26, 2005, from http://www.civilrightsproject.harvard.edu.

Hochschild, J., \& Scovronick, N. (2003). The American dream and the public schools. Oxford, MA: Oxford University Press.

Hokenmaier, K. (1998). Social security vs. educational opportunity in advanced industrial societies. American Journal of Political Science, 42(2), 709-711. Individuals with Disabilities Education Improvement Act. (2004). 20 U.S.C. $\S 1400$.

Itkonen, T. (2005). Vanhempienryhmät USA:n erityisopetuspolitiikassa [The role of parent advocacy groups in the U.S. special education policy]. Yhteiskuntapolitiikka [Finnish Journal of Social Policy], 5, 529-534. Jahnukainen, M. (Ed.). (2001). Lasten erityishuolto-ja opetus Suomessa [Children's special care and special education in Finland]. Helsinki, Finland: Stakes.

Jahnukainen, M. (2003). The development of education for all in Finland. In M. Hui, R. Dowson, \& M. G. Moont (Eds.), Inclusive education in the new millennium (pp. 31-37). Hong Kong, China: The Association for Childhood Education International.

Jahnukainen, M., \& Jarvinen, T. (2005). Risk factors and survival routes: Social exclusion as a lifehistorical phenomenon. Disability \& Society, 20(6), 669-682. 
Kingdon, J. (1995). Agendas, alternatives, and public policies (2nd ed.). New York: Harper Collins.

Kirby, S., \& Grissmer, D. W. (1993). Teacher attrition: Theory, evidence, and suggested policy options. Santa Monica, CA: Rand Corporation. (ERIC Documentation Reproduction Service No. ED364533)

Kivirauma, J. (2001). Erityisopetuksen historialliset kehityslinjat Suomessa [The historical development of special education in Finland.] In M. Jahnukainen (Ed.), Lasten erityishuolto-ja opetus Suomessa [Children's special care and special education in Finland]. Helsinki, Finland: Bookwell.

March, J. G., \& Olsen, J. P. (1989). Rediscovering institutions: The organizational basis of politics. New York: The Free Press.

Mayer, S. E. (1997). What money can't buy: Family income and children's life changes. Cambridge, MA: Harvard University Press.

McDonnell, L. M. (2005). No Child Left Behind and the federal role in education: Evolution or revolution? Peabody Journal of Education, 80(2), 19-38.

McDonnell, L. M., \& Elmore, R. F. (1987). Getting the job done: Alternative policy instruments. Educational Evaluation and Policy Analysis, 9(2), 133-152.

McDonnell, L. M., \& McLaughlin, M. J. (1997). Educating one and all: Students with disabilities and standards-based reform. Washington DC: National Academy Press.

Morse, J. (2003). Principals of mixed methods and multimethod research design. In A. Tashakkori \& C. Teddlie (Eds.), Handbook of mixed methods in social \& behavioral research. Thousand Oaks, CA: Sage Publications.

No Child Left Behind Act. (2002). 20 U.S.C. § 6301.

Organization for Economic Cooperation and Development. (2001). Education at a glance. Paris, France: OECD.

Perustusopetuslaki [Comprehensive School Law]. (1998). Helsinki, Finland: Government Finland.

Powers, J. M. (2004). High-stakes accountability and equity: Using evidence from California's public school Accountability Act to address the issues in Williams v. State of California. American Educational Research Association, 41(4), 763-795. 
Program for International Student Achievement, 2000 (2003). Retrieved December 18, 2005, from http://www.pisa.oecd.org/dataoecd/58/57/33918098.pdf.

Rothstein, R. (2000). Equalizing education resources on behalf of disadvantaged children. In R. D. Kahlenberg (Ed.), A notion at risk: Preserving public education as an engine for social mobility (pp. 31-92). New York: Century Foundation.

Schrag, J., \& McDougall, D. (1997). Special education classroom study. Honolulu, HI: Felix Monitoring Project.

Shoukri, M. M. (2003). Measures of interobserver agreement. New York: CRC Press.

Simola, H. (2005). The Finnish miracle of PISA: Historical and sociological remarks on teaching and teacher education. Comparative Education, 41(4), 455470.

Statistics Finland. (2002). Opettajankoulutuksen 1990-luvulla suorittaneet. Erillisaineisto. Unpublished manuscript.

Statistics Finland. (2005). Erityisopetus [Special education]. Retrieved January 14, 2006, from http://www.stat.fi/til/erop/index.html.

Superfine, B. M. (2005). The politics of accountability: The rise and fall of Goals 2000. American Journal of Education, 112(1), 10-43.

U.S. Department of Education. (2003). Twenty-third annual report to Congress on the implementation of the Individuals with Disabilities Education Act. Washington, DC: U.S. Government Printing Office.

U.S. Department of Education. (2005). Twenty-fifth annual report to Congress on the implementation of the Individuals with Disabilities Education Act. Washington, DC: U.S. Government Printing Office.

U.S. Census Bureau. Census 2000. Retrieved January 16, 2006, from http://www.census.gov/main/www/cen2000.html.

Vaughn, S., \& Fuchs, L. S. (2003). Redefining learning disabilities and inadequate response to instruction: The promise and potential problems. Learning Disabilities Research \& Practice, 18(3), 137-146.

Weatherly, R., \& Lipsky, M. (1977). Street-level bureaucrats and institutional innovation: Implementing special education reform. Harvard Educational Review, 47(2), 171-197. 
Wilson, J. Q. (1989). Bureaucracy: What government agencies do and why they do it. New York: Basic Books. 